\title{
ATTITUDES OF NATO, SCO AND CSTO TOWARDS THE SITUATION IN AFGHANISTAN AFTER 2014
}

\author{
Łukasz Jureńczyk ${ }^{1}$ \\ Jildiz Nicharapova²
}

\section{Introduction}

After the end of the Cold War, there was a growing conviction that because of the dominant position of the North Atlantic Treaty Organization in the world, member states were not threatened by a conventional military aggression. For this reason, the Alliance focused on counteracting unconventional risks that potentially and virtually threatened the states of the North Atlantic zone. Due to the threat posed by Islamic radicals, international terrorism was recognized as one of the most serious risk to the Alliance's member states. Currently, combating the phenomenon of international terrorism is one of the priorities of the North Atlantic Alliance, which is reflected in a number of documents, including the 2010 Lisbon Strategy. The Afghanistan-Pakistan borderland is the epicenter of international terrorism. Al-Qaeda and the Taliban have their main operational and recruitment base in this area, and they are also supported by local entities, including Inter-Services Intelligence (ISI) of Pakistan. Other terrorist organizations, including, above all, the so-called Islamic State, also strengthen their influence in Afghanistan. Fighters of international jihad operate globally, therefore their aims are also citizens of Western countries. This means that NATO and the Afghan authorities have a common goal in the fight against these organizations (Balkhi 20I6, II2-II3, II6). Afghanistan is a failed state, from which many other threats emerge, consequences of which also affect NATO countries. Among them, the production and trafficking of drugs on a global scale, or the

I Head of the Department of Security Policy, Faculty of Political Sciences and Administration, Kazimierz Wielki University in Bydgoszcz, Poland. E-mail: lukaszjurenczyk@ukw.edu.pl 2 Associate Professor, PhH, Head of Research Office, American University of Central Asia in Bishkek, Kyrgyz Republic. E-mail: jildiz.nicharapova@gmail.com 
destabilization of neighboring regions like Central Asia and the Middle East, that are very important suppliers of energy resources for the West.

The never-ending power vacuum in Afghanistan continues to be the most critical factor to the security in Central Asia because of internal turmoil in Afghanistan and strategic agendas of external actors (Vielmini 20I2, 4). Central Asia is as much a problem for Afghanistan as Afghanistan is a problem for Central Asia. China faces some significant and direct threats towards its own national security - extremism, organized crime, heroin and opium originate from Afghanistan (Swanstorm 20I3, 3I-32).

According to most of the scholars the situation in Afghanistan is far from stabilized (Nopens 20I4, I). The departure of NATO forces and most US forces from Afghanistan leaves behind a weak and poorly functioning state, a high level of instability, continuing insurgent and other violence and an opium economy much larger in size than it was a decade ago. On the one hand, this raises serious concerns among the states of the region and powers adjacent to the region, including Russia, about potential repercussions of the US/NATO withdrawal for regional stability. On the other, the withdrawal of foreign military forces may in fact open the way for real negotiations on the intra-afghan political settlement (Stepanova 2013, 2). Two opposite narratives exist about the impact of a withdrawal. The Afghan and Western governments claim that Afghanistan will be capable of guaranteeing its own security and there is no significant risk of spillover to the region. Conversely, the states of the former Soviet Central Asia (FSCA) and Russia, and regional international organizations such as the CSTO and, to a lesser degree, the SCO, predict a serious spillover into neighboring countries and beyond (Nopens 2014, 5).

The Shanghai Cooperation Organization is a China-led organization in the region, which created in 200 I by China, Russia, Kazakhstan, Kyrgyzstan, Uzbekistan and Tajikistan. Its main aim of creation was security namely fights against three evils - terrorism, extremism and separatism as well as other issues of security (Convention of the SCO on terrorism, extremism and separatism and Charter of the SCO sectsco.org). Despite there is also Russia as a founder the $\mathrm{SCO}$ is seen mostly as Chinese tool for forwarding its politics in Central Asia.

Russia also possesses a security organization which was created in 2002 - Collective Security Treaty Organization. The CSTO, formed in 2002, today consists of Armenia, Belarus, Kazakhstan, Kyrgyzstan, Russia and Tajikistan. It is gradually evolving from a military alliance to a more multifunctional organization addressing many security issues. Russia, by far the biggest member, dominates the organization's development and contributes most resources, but needs the cooperation of the smaller states 
to enhance its legitimacy. The CSTO is probably the main effort to build both capacity and legitimacy for possible military intervention to address security concerns in Central Asia as the international military effort in Afghanistan is being reduced (Norberg 2013, 6).

Our main research question is what attitude NATO, SCO and CSTO present toward Afghanistan after 2014? Side questions are what are the reasons of involvement of NATO and non-involvement of CSTO and SCO into Afghanistan before 20I4? What did they do to solve security issues in Afghanistan before 20I4? Are SCO and CSTO as much as NATO concerned with situation in Afghanistan after 20I4? Will they be involved in this country in the future? What are their vision and position in solving Afghan problem? How can they be involved in solving Afghan problems? Are they implementing policy concerning Afghanistan after 20I4? How destabilization of Afghanistan affected these organizations? Did the Afghan crisis conduct to strengthening of anti-terrorist and anti-narcotic cooperation and politics? In our research we will analyze their activities, policy and intentions before 2014 and what changes happened (and if they happened?) in these organizations concerning Afghanistan after 20I4?

Section two will discuss the literature review and theoretical approach in analyzing the NATO, SCO and CSTO involvement in Afghanistan stabilization process. Different theory of international relations will be applied in order to explain involvement and interest of these organizations in Afghan issues. According to theories of IR why should NATO, SCO and CSTO be interested and involved in Afghanistan? What are the main reasons of NATO, CSTO and SCO possible involvements in Afghanistan? Why they should be interested in Afghan issues? The third sections will focus on NATO's activities in Afghanistan before 20I4. The answer will be given to the questions about NATO's role played in Afghanistan at that time? What were the successes and failures? What were the main barriers during the missions? The fourth will show NATO's approach to Afghanistan in the decisions of the Alliance summits. It will show what is the prospect of further NATO involvement in Afghanistan? The fifth section will be devoted to the real activities carried out by NATO in Afghanistan after 20I4. This will allow us to answer how NATO's activities in Afghanistan changed after 20I4? Whether these changes bring the desired result? Section six will be focused on SCO role in stabilizing Afghanistan. What had the SCO done already since its creation and what are its intentions towards Afghanistan in the future? What role it can play in this process? Section seven will analyze the attitudes of the CSTO towards Afghan crisis and its future possible role. Afghan crisis will impact all CSTO members including Russia especially drug trafficking, terrorism and extremism issues 
will influence national security of CSTO and SCO states not mentioning other issues like ethnic clashes in the border, arms trafficking, refugee issues, etc.

\section{Literature Review and Theoretical Framework}

The mission in Afghanistan is carried out by NATO in an area far beyond the North Atlantic zone. However, the member states were involved in the mission in this country, because it was justified by the threat from Al Qaeda, which despises and wants to combat the West's values and way of life (Schimmelfennig 20I6, Io8). In NATO, rhetoric was maintained that whoever is not ready to go to Afghanistan must be ready for "Afghanistan to come to them", which was associated with the spreading of terrorist threat. One of NATO's main goals was to prevent Afghanistan from becoming a safe haven for terrorists once again (Behnke 20I3, I67). Thanks to this, it was possible to maintain relative solidarity in NATO around the conducting of the mission in Afghanistan.

For many reasons, Afghanistan needs help from NATO. First of all, this concerns security and defense issues. Afghanistan does not have enough resources for training, arming and maintaining security forces in the size of several hundred thousand, which would effectively face the antistate opposition. This need also applies to a number of other areas of action, including the fight against poverty, unemployment, corruption, and human rights violations. Therefore, ensuring a minimum of stability and security in Afghanistan requires a multidimensional approach, which should also focus on economic and social issues (Qassem 2009, I73-I74).

President Barack Obama's approach to Afghanistan assumed a temporary increase in military personnel and intensification of combat operations. This was to shortly lead to a relative stabilization of the situation in the country and allow the withdrawal of soldiers. The increased presence and military activity of NATO forces was to last only during the transition period, until the Afghan security forces were able to take over the responsibility for maintaining security in Afghanistan (McCrisken 20I4, 36). However, this approach did not bring the expected results, because after the withdrawal of NATO troops from Afghanistan, Afghan security forces are not able to carry out the task entrusted to them.

Since most of the SCO countries are geographically contiguous with Afghanistan, and thus are vulnerable to spillover effects of terrorism and Afghan-originated drug trafficking. Indeed, Afghan issue occupies importance throughout the history of SCO (Raja Muhammad Khan 20I5, 
6). The main way Afghanistan relates to the Central Asia is through their concern for a spillover of instability post-20I4 (Nopens 20I4, 3). And it is the same for CSTO countries, which include the same members.

In both structures Central Asian states except Turkmenistan participate and are the founders. These both structures are concerned with security issues existing in Central Asia and Afghanistan. Afghanistan is seen as a main sources of security issues for Central Asia and accordingly for Russia and China. ISAF's withdrawal from Afghanistan in 20I4 directly impacts the wider region including not only Central Asia but China and Russia as well (Nopens 20I4, I).

Should the risks linked to Afghanistan materialize, the first victims would be the states of the CA, but the burden of countering them would fall primarily on Russia and China. China's main concerns are insurrection spreading to Uighur separatists and instability in the CA, substantially raising the cost of integrating the region in its resource base. Russia's main concerns are instability in the Former Soviet Central Asia spreading to the Russian Federation and drug trafficking (Nopens 20I4, 5).

While the SCO excludes the possibility of sending troops to Afghanistan, it could play a significant role in political developments (Huasheng 20I2, I3). For Afghanistan, involvement in regional economic cooperation is the natural way to develop its economy, with the SCO as one of the most suitable frameworks for Afghanistan to join. Many ways are possible for the SCO and Afghanistan to cooperate, such as in trade, transportation, energy, agriculture, and investment. As neighboring countries, SCO states are the most convenient trading partners for Afghanistan. Currently, Pakistan, India, and Iran are the top three-largest importers for Afghanistan; and Uzbekistan, China, and Pakistan are the top three exporters. All of them are SCO countries (with Iran as an observer) (Economic and Commercial Counselor's Office of the Embassy of PRC in Afghanistan 2011).

In analyzing activities and purposes of existence there are different theoretical approaches. The realist approach indicates that international organizations for all intents and purposes are the tools that powerful states use to control weaker countries. And if IOs are extensions of great powers, they respond only to great powers interests and direction. When the security interests of the great powers conflict, IOs are either discarded, ignored or are marginalized by the states that created them (Pease 2008, 44). IOs play little or no role in maintaining international peace and security. Balance of power realities dictate or not, war will break out. States will bypass or ignore IO if their immediate security or important national interests are at stake (Pease 2008, 56). Schweller and Preiss (I997) pointed out that international 
organizations perform several functions: first, IOs provide a mechanism for great power collusion. Second they are useful for making minor adjustments within the existing order while the basic underlying principles and norms remain uncompromised.

Liberals see international relations as a mixture of cooperation and conflict and argue that international organizations can play a positive, constructive role in promoting international stability and global welfare (Pease $2008,58)$. Liberalist approach accenting on valuable role of IOs in maintaining peace and security in the world and that international organization are the independent actors in world politics. Liberalism is more optimistic than realism about the contributions and independence of IO in IR (Pease 2008, 67).

Five interrelated roles can be discerned from the liberal approach. IO help states overcome collective action problems; Promote economic prosperity and global welfare; IOs help societies develop shared values and norms. Interdependence may reduce the chances of violent conflict. IOs foster certain values and help establish certain norms that are conducive to the peaceful settlement of disputes, such as compromise, reciprocity, multilateralism, and rule of law. IOs promote democracy and democratic institutions, protect human rights, promote liberal international economic order; Integrative and performed principally by MNCs common global market; provide assistance to the victims of international politics, poor, refugees, epidemics, disasters, war, economic crises (Pease 2008, 67-7I).

While justifying the need for military intervention in Afghanistan, liberal rhetoric was primarily used. First of all, the necessity to protect Western values against the barbarism of Islamic radicals was pointed out. The need to help the people of Afghanistan and their protection against crimes and oppression from fanatics was also highlighted. Promotion of democratic values and defense against tyranny are consistent with the theory of liberalism and give a kind of mandate to the international community to coercive intervention and statebuilding (Kerton-Johnson 20II, I45-I46).

Later, realistic premises began to come to the fore. This was largely the result of President Barak Obama coming to power in the United States. His "realism of limits" was a response to the global activities of his predecessor. President Obama has stated that the United States cannot take the burden of solving all global problems due to limited resources. In Afghanistan, he wanted to narrow the scale of activities to counterinsurgency goals (Renshon 20I0, 6, I5). The end of the NATO combat operation in Afghanistan was a manifestation of the restraint and realistic approach (Quinn 20I4, 9).

During the presidency of Donald Trump, NATO involvement in 
Afghanistan increased to some extent. Despite this, his approach also partly fits in with the theory of realism. With limited resources, there is an attempt to maintain a minimum of stability in Afghanistan. However, both Barack Obama's and Donald Trump's approach to Afghanistan are diffuse and diverse and cannot be clearly included in one theoretical paradigm.

Also the attitudes of other international actors in Afghanistan namely SCO and CSTO can be analyzed with the help of these above-mentioned theories. Realists view in their actions only their national interests and great game between the great powers. They don't intend to assist peace in Afghanistan but are pursuing their selfish goals. In our opinion, instability and conflict in Afghanistan is somehow beneficial for Russia and China. First of all, this is due to the defeat suffered by NATO in this country. On the other hand the unstable situation in Afghanistan generates a number of threats that negatively affect these great powers. Liberal approach will show that international actors create such organizations like SCO and CSTO in order to collectively solve the Afghan problem.

\section{Assessment of NATO's Activity in Afghanistan Before 2014}

September I2, 200I was a landmark day in NATO's history. For the first time, article 5 of the Washington treaty, constituting a collective defense of the members of the Alliance in case of aggression on one of them, was launched. This was surprising because was invoked on behalf of the United States, and the aggressor was a terrorist organization. Unlike later military intervention in Iraq, in the case of Afghanistan European allies expressed their unity with the Americans. The discussion at that time in NATO did not concern whether the operation in Afghanistan should be carried out, but what should be the division of tasks and responsibilities between the members of the Pact (Kitchen 20I0, 96). During the military intervention in Afghanistan, US cooperation with allies was mainly bilateral. The Enduring Freedom operation was not formally carried out by NATO because Washington did not want to be restricted in its actions by the Alliance. Nevertheless, NATO provided the infrastructure support necessary for its implementation, as well as took a number of measures to relieve the Americans so that they could prepare themselves for the operation (Treverton 2016, 50). This showed that in order to carry out combat operations, the United States did not need significant support from the allies. The operation was swift and victorious, but the way it was carried out let flee from Afghanistan thousands of militants and terrorists who later returned to the country with the intention of destabilizing it. 
The Americans needed as much support from the allies as possible during the post-war stabilization of Afghanistan within the International Security Assistance Force (ISAF) mission. At that time, NATO began to play a significant role in that country. However, the dominant position and the incomparably highest level of involvement were still on the US side (Terzuolo 2006, 8I). The US personnel, equipment and financial contribution to the mission in Afghanistan significantly exceeded the contribution of all other NATO countries. Nevertheless, it was the next step on the road to globalization of the Alliance's activities and taking over the role of the so-called "world gendarme". The NATO mission in Afghanistan, just like previous missions in the Balkans, has once again shown that Alliance must have modern, welltrained and mobile armed forces if it wants to act effectively on the world stage (Orfy 20II, 87).

For many years, the mission in Afghanistan was perceived as the most urgent and the most important issue of security for the North Atlantic Alliance. In addition, it was a test of NATO's solidarity, cohesion and efficiency (Bindi 20I5, 49). At the peak of the ISAF mission in Afghanistan, over I30,000 soldiers from 50 countries, including 28 member states of the Alliance, stationed in the country. European NATO member states engaged in the mission in Afghanistan because they wanted to maintain their political influence in the Alliance. Failure to support Americans could lead to a significant weakening of the transatlantic bond (Simoni 2013, II5, I26). However, the mission in Afghanistan, as well as the mission in Iraq, showed a difference in the approach to military activity between Kantian Europe and a Hobbesian America, although the gap was not so drastic (Lagadec 20I2, 48). Many Western European states have criticized the US that it was not seriously considering their opinion on nation-building goals. On the other hand, the United States have criticized these countries for the reluctance or inability to conduct military struggle against the Taliban insurgency (Keane 20I6, 6).

The missions in Afghanistan led to the removal of the Taliban from power, weakening Al-Qaeda and killing its leader Osama bin Laden. They also allowed to achieve significant progress in terms of the standard of living of Afghan people and respect for human rights. Unfortunately, NATO has faced many challenges and problems in Afghanistan, and some of them have been self-inflicted. NATO's military forces wanted the Afghans to beware of the Taliban and adopt Western systemic solutions, including democracy and a broad catalog of human rights. However, these changes should not be imposed from outside, in a short time and through foreign military forces. NATO countries have not sufficiently taken into account the profound difference in the approach to these issues between Afghans and Western 
societies. The world in which Afghans live is completely different from the West, and thus their perspective is different. The fragmentation of society, the lack of centralizing tradition of governing the country, close attachment to traditional Islamic principles, deep corruption, widespread poverty and illiteracy are just some of the barriers to the introduction of modern system solutions in Afghanistan (Lawless, Constantineau, Dizboni 2017, s. 65-66). The rapid modernization of the country caused resistance of fundamentalist circles and jihadist organizations which opposed the changes. Because the anti-state opposition destabilizes Afghanistan and gradually extends its influence in the country, the successes of NATO and the West of recent years may prove to be unstable. Due to insufficient planning capabilities and limitations of resources needed to carry out tasks, NATO had limited possibilities to influence the security environment in Afghanistan (LindleyFrench 2013, I33).

Many influential think-thanks, including the Afghanistan Study Group, recognized that the withdrawal of NATO troops from Afghanistan was both wise and necessary. They considered that the presence of NATO troops in Afghanistan is one of the main reasons for rebellion in that country. Along with the increased involvement of Alliance forces in Afghanistan, the Taliban grew in strength and rebuilt its influence in the subsequent parts of the country. To reverse this direction, it was considered legitimate to apply a reverse approach that was based on the gradual disengagement of the U.S. and NATO military forces (Cortright 20I6, 6-7). However, this conviction is not justified by the development of the situation in Afghanistan after 2014 . Anti-state forces have intensified military activity, exert increasing pressure on the Afghan authorities and force NATO leaders to review the withdrawal policy.

\section{Afghanistan in the Decisions of NATO Summits After 2014}

The weakness of the ISAF mission in Afghanistan and the outbreak of the crisis in Ukraine caused the shift of emphasis in NATO from the intensively developed in post-Cold War era Non-Article 5 crisis response operations towards neglected in recent decades article 5-based collective defence and deterrence. In the declaration from NATO summit of Newport, which took place on 4-5 September 20I4, the allies reaffirmed their commitment to fulfill three main tasks, i.e. collective defense, crisis management, and cooperative security. In the area of crisis response operations, they focused mainly on Afghanistan. They stated that the ISAF mission has led to increase of the world security and to improve the existence of Afghans. Allies ensured the 
adaptation of the mission in Afghanistan to changes resulting both from the progress achieved and the remaining challenges. They confirmed the end of the ISAF mission by the end of 2014 and thus the change of the NATO engagement formula in Afghanistan. Member states also confirmed their determination to support the government of Afghanistan in creating a stable, sovereign, democratic and unified state, free from terrorism (Wales Summit Declaration 20I4).

On the first day of the summit there was a meeting devoted to the situation in Afghanistan. The effect of the talks was issuing a joint declaration, which detailed the provisions regarding Afghanistan included in the general declaration of the summit. The document appreciates the dedication of personnel taking part in the ISAF mission. It emphasized their contribution to the development of the security sector of Afghanistan, human rights, and the economic and social sphere. It was announced that with the end of the ISAF mission, the Afghan authorities would assume full responsibility for state security. Three parallel mutually complementary engagements were announced: in the short term, to train, advise, and assist the Afghan National Defense and Security Forces (ANDSF) through the non-combat Resolute Support Mission (RSM); in the medium term, to contribute to the financial sustainment of the ANDSF at least to the end of 20I7; in the long term, to strengthen cooperation and regular consultation on issues of strategic concern through NATO-Afghanistan Enduring Partnership agreed at the Lisbon Summit in 20I0. In addition, NATO announced its continued support for Afghanistan's peace process and cooperation with its neighbors and the international community (Wales Summit Declaration on Afghanistan 20I4).

The NATO summit in Warsaw held on 8-9 July 2016 focused on specifying actions to secure the Alliance's eastern flank in the face of Russia's military policy in Eastern Europe. Nevertheless, NATO has confirmed its commitment to long-term security and stability in Afghanistan. Other goals were also sustained for Afghanistan, including its multidimensional development and counteracting the terrorism (Warsaw Summit Communiqué 20I6). During a meeting devoted to Afghanistan it was decided that NATO troops would stay in that country after 2016 in order to support the development of Afghan security forces. Allies also decided to finance ANDSF at least until 2020 (Larsen 20I7, I3). The commitment to strengthen and enhance the Enduring Partnership between NATO and Afghanistan was also declared (Warsaw Summit Declaration on Afghanistan 2016).

The two main points of the agenda during the one-day NATO summit in Brussels on May 25, 2017 was to increase the Alliance's commitment to combating terrorism in the world and a more balanced bearing of the costs 
of Alliance's functioning. Secretary General Jens Stoltenberg said that in the case of Afghanistan, the best way to combat terrorism was to continue training Afghan security forces. Increasing the financing of the army by member states to a minimum of $2 \%$ of GDP is intended to enable the Alliance to both develop defense capabilities and continue out of area crisis response operations, including the mission in Afghanistan (Doorstep Statement... 20I7).

The declaration ending the NATO summit in Brussels, which took place on II-I2 July 20I8, stated that Resolute Support Mission was achieving success in training, advising, and assisting the Afghan security forces. The period of financing of ANDSF was prolonged until 2024 and allies pledged increased efforts to fill in the employment gaps in these forces. The NATO also assured the support to the Afghan peace process, and called other countries to do the same (Brussels Summit Declaration 2018). In the joint statement concerning RSM allies sustained the mission's objectives, in particular emphasizing the need to strengthen Afghan security forces and to support their fight against terrorist organizations, mainly Al-Qaeda and ISIS. At the same meeting, an appeal was made to the Taliban to join the peace process and to sing eventually the peace agreement with the Afghan government (Joint Statement... 20I8).

At the NATO summit in London on December 3-4, 20I9, very little attention was paid to Afghanistan. However, the heads of state and government confirmed their commitment to long-term security and stability in the country (Brussels Summit Declaration 2018).

\section{NATO Activities in Afghanistan After 2014}

After 20I4, NATO is still committed to the mission in Afghanistan. Currently, NATO support for Afghanistan is implemented in three main areas:

- The NATO-led Resolute Support Mission,

- Funding of the ANDSF,

- NATO-Afghanistan Enduring Partnership.

By the end of 20I4, full responsibility for the security of Afghanistan was transferred to Afghan security forces. As a result, most of the combat units of NATO and partner countries have been withdrawn from Afghanistan. The exception was with some special forces, training units and other unconventional units. The United States sought to ensure that the mandate of forces remaining in Afghanistan would include tasks of training of Afghan army and police, and counter-terrorism activities, mainly against Al-Qaeda 
and Islamic State. If necessary, these forces would also prevent the collapse of the Kabul government. These actions are referred to as "beyond the horizon" (Ruttig 20I4, I86).

NATO leaders decided to appoint on January I, 20I5 smaller than ISAF, but still valid, Resolute Support Mission. It was launched in accordance with United Nations Security Council Resolution 2189 of 2014 and at the invitation of the Afghan government. NATO-led, non-combat mission is designed to train, advise and assist the Afghan security forces and institutions (Ringsmose 20I6, 2I3). Its aim is to help the Afghan security forces and institutions develop the capacity to reach and maintain peace and security in the country. Initially, in the mission served 13,000 troops, however in November 2017 it was decided to increase the limit to the current 16,000 troops from 39 member and partner states of NATO. The RMS operates with a central hub in Kabul / Bagram and four spokes - Mazar-e-Sharif in the north, Herat in the west, Kandahar in the south, and Laghman in the east. Mission mostly focuses on training, advice and assistance activities at the securityrelated ministries, in the country's institutions and among the senior ranks of the army and police. Key functions of the mission include (Resolute Support Mission...):

- "Supporting planning, programming and budgeting;

- Assuring transparency, accountability and oversight;

- Supporting the adherence to the principles of rule of law and good governance;

- Supporting the establishment and sustainment of such processes as force generation, recruiting, training, managing and development of personnel".

NATO Allies and partners are helping to sustain Afghan security forces and institutions financially. Funding of the Afghan security forces is as part of a broader international effort in the financial support of Afghanistan. Even before the end of the ISAF mission, NATO announced the reduction of the number of ANDSF from 352 to 228,5 thousands. Reduction of forces is to be made possible by their professionalization as well as by increasing stability and security in Afghanistan. Annual budget of ANDSF was estimated for 4.I billion USD (Jureńczyk 2016, 58). Afghanistan's yearly share in financing ANDSF would have increase progressively from at least 500 million USD in 2015 to the full financial responsibility for its own security forces no later than in 2024. At the same time the international contribution would gradually decrease from at least 3.6 billion USD in 2015 to 2.5 billion USD in 2020 and would be done in 2024 (Byrd 20I4). Numerous member states and partners 
of NATO do not comply with the ANDSF co-financing declarations within the ANA Trust Fund. By November 20I9, the fund was funded with just USD 2,9II million (Afghan National Army... 20I9). Financial shortages are topped up by the United States through other funds like Law and Order Trust Fund for Afghanistan (LOTFA), administered by the United Nations Development Programme (UNDP), and the United States Afghanistan Security Forces Fund (ASFF) (NATO-Afghanistan relations 2018, 2).

In 20I0 NATO and Afghanistan signed a Declaration on Enduring Partnership. This cooperation was to be implemented through political dialogue and practical cooperation. Partnership with Afghanistan is a part of the NATO global partnership network and underlines the strategic importance of the Alliance's engagement in Afghanistan. In 2016 NATO decided to strengthen and enhance the Partnership, both within and alongside RSM. Currently, the maintenance and development of the partnership remains one of NATO's long-term goals towards Afghanistan. Political leadership of the Alliance is represented in Kabul by NATO's Senior Civilian Representative. He plays a leading role in advising the Afghan authorities on the Enduring Partnership. In addition, he acts as an intermediary in cooperation between the Afghan government and representatives of the international community and neighboring countries. Within the Enduring Partnership, the following objectives are implemented (NATO and Afghanistan 20I8):

- Building Integrity Programme to promote good governance and implement the principles of integrity, transparency and accountability in the security sector and reduce the risk of corruption,

- Defence Education Enhancement Programme as practical support to Afghanistan in developing and reforming their professional military education institutions,

- training in the fields of civil emergency planning and disaster preparedness,

- promoting a better understanding of NATO and its role in Afghanistan.

In the field of support for economic and social development, by the end of 20I4 Provincial Reconstruction Teams had been phased out and their functions were handed over to Afghan authorities. In this way, NATO ceased to be the main instrument through which the international community provided support for Afghanistan's economic and social development. Nevertheless, NATO member states, mainly the United States, are still the main contributors to international funds for the development of Afghanistan. 


\section{SCO and Afghanistan}

According to some scholars the SCO's central focus on security, particularly terrorism, separatism, and extremism, is also an opportunity for the organization to play the prominent role in maintaining stability in post-20I4 Central Asia (Reeves 20I4, 6). But the space created for the SCO to operate in Afghanistan's stabilization is limited in scope due to the U.S./ NATO military presence inside Afghanistan as well as certain inherent organizational limitations (Khan 2009, 5).

The SCO has been forming a common approach to the Afghan problem within the entire period of its activity and they have special relations with each other (Huasheng 20I2, IO). In 2005, the Protocol on Establishment of the SCO-Afghanistan Contact Group between the SCO and the Islamic Republic of Afghanistan was signed in order to provide a mechanism for the SCO member States to jointly contribute to reconstruction and stability in Afghanistan. President Karzai has also attended all SCO summits (Khan 2009 , 6). In 2012 Afghanistan was attributed status of observer state in the SCO. Uzbekistan at the time proposed formula "Six plus Three" for the solution of the Afghan problem, which means the involvement of Afghanistan's six direct neighbors, as well as Russia, the US and NATO (Baubek, Yesseanalieva, Adil 20I5, 5I5).

The SCO Special Conference on Afghanistan was held in March 2009 in Moscow. The SCO-Afghanistan Action Plan calls for joint operations in combating terrorism, drug trafficking and organized crime; for involving Afghanistan in a phased manner in SCO-wide collaboration in fighting terrorism in the region; and for inviting relevant Afghan State institutions to take part in law-enforcement exercises conducted by the SCO. It also provides for stepping up the training of drug agencies, combating drug money laundering and improving border control. These measures are designed to set up anti-narcotics, anti-terrorism and anti-money laundering security belts around Afghanistan (Khan 2009, 6).

SCO has laid down its views regarding Afghan policy and they are: promote political stability and economic development in Afghanistan, build a stable terrorism, narcotics and poverty-free Afghanistan, encourage the country to build an environment favorable for good relations with the neighbors, and further maintains that the international community must assist using the platform of United Nations (Huasheng 20I2, IO).

As presumed by scholars, the biggest test of the SCO would be its developmental role in post-20I4 Afghanistan. Looking at China's growing 
attention of Afghanistan, it becomes clear that China is well aware of all these realities and is ready to make an effort to ensure regional stability connected to that of Afghanistan. Former Chinese President Mr. Hu once said that, "China will continue actively participating in international and regional cooperation concerning Afghanistan" (Bryanski and Buckley 20I2).

The main position of the SCO towards Afghanistan has been that the Afghan conflict cannot be solved by military means it can only be solved by economic means by building infrastructure and through economic and social assistance (Joint Communiqué in 20II, Astana).

From SCO forum in June 20I2, China clearly expressed its desire to play a greater role for the stabilization of Afghanistan alongside Russia (Raja Muhammad Khan 20I5, 6). China would play a role to manage the regional affairs against the "shocks from turbulence outside the region" and that would also include reconstruction of Afghanistan and rehabilitation of Afghan population (Bryanski and Buckley 20I2). SCO does not distance itself from the Afghan problem. If the Western coalition is going to leave the country, the SCO will stay due to its geographical proximity. The uncontrolled situation in the country is a big risk for the nearest neighbors (Baubek, Yesseanalieva, Adil 20I5, 515).

According to Mr.Zhang Deguang, Chairman of China Foundation of International Studies (CFIS), "SCO can and will play a bigger role in Afghanistan after the NATO withdrawal" (Bryanski and Buckley 20I2). He added that China would provide \$io billion for undertaking projects in the SCO countries. Chinese Foreign minister Yang Jiechi also motioned that the role of the SCO and other existing international organizations and cooperation mechanisms should be brought into full play during Bonn Conference in 2011 .

Member states of the SCO worry about the future developments in Afghanistan. Tajikistan, Uzbekistan, China, Pakistan are the members and Iran and Afghanistan are observers in the SCO and Turkmenistan attends as a guest (Nopens 20I4, 5).

In March 2009, the SCO framed a detailed "Plan of Action of the Shanghai Cooperation Organization Member States and Islamic Republic of Afghanistan on combating terrorism, illicit drug trafficking and organized crime". In March 28, 20I4, a meeting of the Board of the RATS took a decision on protective measures against the terrorist threat emanating from Afghanistan due to the withdrawal of coalition troops from the country (20I4). Many of the SCO member states have programmes of assistance to Afghanistan on a bilateral basis. China takes the most active steps in this direction. China's strength in this regard compared with Russia and the United States is that it 
has a neutral player reputation (Baubek, Yesseanalieva, Adil 20I5, 5I5).

Russia and China prefer to give the central role for the post-20I4 phase to the United Nations. Nevertheless, they are interested to maintain the SCO, where nearly all the countries surrounding Afghanistan are either members or observers, as positive political platform for the resolution of the conflict and an instrument for stability, also with the anti-terrorist capacities developed with the organization (Vielmini 20I2, 7).

The SCO is not going to be presented in Afghanistan as a military contingent. However, at the summit in January 20II, the SCO member states declared their readiness to cooperate with NATO on special projects, related to security at the borders of Afghanistan (Baubek, Yesseanalieva, Adil 20I5, 5I5). The SCO opposed resorting to military means to reach a settlement, maintaining that solving the internal disputes militarily would be impossible (Huasheng 20I2, IO).

The SCO is well positioned to play a role in establishing cooperation, or rather coordination, on how best to assist Afghanistan in providing for security, stability, and development in the future. The SCO kind of multilateralism is well suited to a region with complex and frequently changing patterns of conflict and cooperation between the major and small powers. The SCO provides multilateral policy coordination and a platform that facilitates bilateral cooperation on issues of central importance to Afghanistan such as terrorist threats, transnational crime, and economic integration. The flexible structure and inclusive character of SCO makes it suitable for inter-state initiatives that might help China deal with some of the problems that flow from Afghanistan (Liselotte Odgaard 2013, 45-46). While endorsing the participation of the international community in settling the Afghan issue, the SCO emphasized the central position of the United Nations, which, it believed, should play the leading and organizing role in this effort. The SCO supported the " 6 plus 2" model, with "6" referring to the six neighbors of Afghanistan-China, Tajikistan, Uzbekistan, Turkmenistan, Iran, and Pakistan—and "2" referring to Russia and the United States. That said, the SCO has stated explicitly that it "opposes any external forces using Afghanistan and its territory to commit activities that would jeopardize the regional security" (Huasheng 2012, I0).

Through its 20I3 Bishkek Declaration, the SCO member states have made it clear that the organization will play a central, although unspecified security provider role in Afghanistan and Central Asia following the drawdown of ISAF troops (Bishkek Declaration) and member states also committed to more robust cooperation on countering transnational threats coming from terrorism and drug trafficking, recognizing the instability that the region will likely face post-20I4 (Reeves 20I4, 5). SCO was neither qualified for, nor 
capable of solving Afghan issues on its own (Huasheng 2012, I0).

\section{CSTO and Afghanistan}

The CSTO, as a Russia-led collective defense organization, is the most obvious instrument for coordinating Russia's security response to an eventual spillover with allies from the CA but only in the territory of its members (Nopens 20I4, 4).

The CSTO is in a process to revise its capacities further in order to tackle the potential threats to come from Afghanistan. It has established effectively multilateral Collective Rapid Reaction Force (CRRF), which are active in training exercises aimed at the prevention of possible incursions Afghanistan as well as possible internal popular uprisings. The CSTO foresees to assist Afghan security forces with training and equipment maintenance but it excludes however any direct deployment on the Afghan territory (Vielmini 2OI2, 5). Russia is the main contributor to all of the CSTO's forces (Norberg 20I3, II) and the main actor who identifies the strategy and action of the CSTO. It is not a secret that the CSTO is dominated by Russia. It means that future involvement or not involvement of the CSTO in Afghan crisis will depend on Russia. As Johan Norberg mentioned Russia clearly dominates the CSTO (Norberg 2013, 34).

Secretaries of the CSTO member states' various security councils have discussed how possible developments from Afghanistan can affect CSTO member states. Mr.Bordyuzha has underlined that the alliance does not plan to intervene inside Afghanistan, but is concerned with possible threats emanating from Afghanistan post-20I4. The two main threats to Central Asia from Afghanistan post-20I4 are likely to be the drugs trade and the influence of extremist Islamic groups. Neither of the two threats would concern CSTO military capabilities; they relate rather to the organization's efforts in counternarcotics and counterterrorism (Norberg 20I3, 32).

At the CSTO summit of 20II, Russia obtained by its partners an agreement according to which, a foreign military presence in the states of the CSTO is possible only with the consent of all the members. Russia seems to be waiting for a NATO depletion, so to have it to accept a security pact with the CSTO, an arrangement that RF is proposing since at least the mid 2000 (Vielmini 2012, 6).

Any direct Russian military involvement or security operations in Afghanistan are ruled out - and will remain so after 20I4. The taboo extends to the Collective security treaty organization (CSTO) - a Russia-led security 
bloc with participation of all the Central Asian states except for Uzbekistan (since 20I2) and Turkmenistan. CSTO secretary-general Nikolai Borduzha has formally excluded any such involvement, noting, "this option has not even been discussed and, hopefully, will never be" (Nesavisimoye voyennoye obozrenije I6 Nov. 20I2). But departure of US/NATO forces from Afghanistan after 20I4 catalyzed Russia's renewed emphasis on Central Asia by Russia's turn from a 'region-wide' approach to Central Asia to closer and more substantive ties with client states Kyrgyzstan and Tajikistan, while assuming greater responsibility for their security. The second change is to expand security assistance and leverage (pledging US\$Ibn in military assistance to Kyrgyzstan and another US\$200m to Tajikistan and finalizing bilateral agreements on Russian military bases and facilities).

Discussing a Russian strategy for Afghanistan after the coalition troop withdrawal Russian scholars mentioned that Russia should enhance security cooperation with CSTO members especially with Kazakhstan. Also they have added that Russia should seek to optimize CSTO's functions and tasks, political component should be strengthened and CSTO academy in Kazakhstan should be established (Trenin, Kulakov, Malashenko, Topychkanov 20I4, 6). This means that Afghan crisis pushes regional organizations to be ready in any time to defend their members.

\section{Conclusion}

After 20I4, rebel and terrorist activity increased in Afghanistan. The drastic reduction of NATO military contingents caused that the anti-state forces gained greater operational comfortableness. Afghan security forces are not able to stop the development of rebel influence in individual provinces and maintain stability and security of the state. NATO is intensifying the training of these forces, but there are still a number of serious problems, including poor level of professionalism, low morale, high level of desertion, large scale of corruption and infiltration by rebel groups. Currently, the Taliban endanger to varying degrees about $70 \%$ of Afghanistan areas. In recent years, the Taliban have begun to exert more pressure on the capitals of individual provinces of the state, and even have been able to take temporary control over Kunduz in northern Afghanistan. In addition, a series of large-scale terrorist attacks has occurred in Kabul in recent years. This is a confirmation that NATO's strategy for Afghanistan, adopted after 2014, is ineffective.

In 20I7, the administration of the president Donald Trump adopted a modified strategy for Afghanistan. It assumes a certain increase in military 
involvement of US and NATO forces in Afghanistan in order to speed up training of the Afghan security forces, as well as to support them in the fight against terrorist and rebel groups. Increased military support is to ensure a better negotiating position of the Ashraf Ghani government, which in February 2018 has offered the Taliban a far-reaching proposal of national reconciliation. From the military perspective, this support mostly focuses on air bombardment, which increases civilian casualties and deepens a spiral of violence in Afghanistan. Additional elements of the strategy embrace cutting of terrorist groups from financial sources and putting bigger pressure on Pakistan. Modification of the strategy is insufficient and the increase of the military involvement is too small to achieve a positive breakthrough in stabilizing security situation in Afghanistan. The peace process pursued by the Afghan government also has not achieved major successes so far, because the Taliban are not interested in cooperating with the government. On the contrary, the goal of the rebels is the armed overthrow of the Afghan government and the re-creation of a fundamentalist regime. To prevent it NATO should consider increasing again its military and non-military engagement in Afghanistan. However, such action would have a positive effect if NATO gained greater support in stabilizing Afghanistan from other countries and international organizations, including SCO and CTSO.

The peaceful nature of the SCO and its focus on economic issues can be a supportive tool to solve the Afghan problem. And the future of the SCO depends on what it would do in Afghanistan (Baubek, Yesseanalieva, Adil $2015,515)$. No other organization except the SCO has the potential ability to draw such disparate states like China, Russia, small Central Asian states, Mongolia, Iran, India, Pakistan and Afghanistan into a single body where they can discuss and work to implement security-related policy. Of all the SCO's strengths, this inclusivity of member and observer states is undoubtedly the greatest (Reeves 20I4, 6). The SCO offers the best opportunities for multilateral cooperation and for mediating divergent regional interests for the stabilization of Afghanistan (Khan 2009, 7).

Of course the SCO was not created solely because of Afghanistan but Afghanistan greatly influences SCO agenda (Huasheng 20I2, IO). Russia's and accordingly CSTO's direct role vis-à-vis Afghanistan is very limited and confined to some economic cooperation, providing some support in arms, equipment and training to the afghan security sector, and transit facilitation for US/NATO forces through Russian territory (Stepanova 2013, 7). Russia has a very genuine interest in supporting any kind of political solution for Afghanistan that could bring relative stabilization (in terms of the end of a major armed conflict) and increase the functionality of the Afghan state. The 
CSTO's military capacity is essentially the same thing as Russia's capacity (Norberg 20I3, 34) and CSTO's position towards Afghanistan will depend on Russia's will.

\section{REFERENCES}

Afghanistan-China Trade Increased Substantially, The Economic and Commercial Counselor's Office. 20II. Embassy of the PRC to Afghanistan. October iI. Available on: http://af.mofcom.gov.cn/aarticle/zxhz/ tjsj/20IIIo/20III07773306.html. access on: September, 20 20I9.

Afghan National Army (ANA) Trust Fund. 2019. November. Available on: $\quad$ https://www.nato.int/nato_static_fl2oI4/assets/pdf/ pdf_20I9_I2/20I9II28_I9I2-backgrounder-ana-trust-fund-en.pdf. access on: December, 72019.

Balkhi, Mirwais. 20I6. "For durable peace and stability: discussing prospects of the NATO membership for Afghanistan”. In: Harshé, Rajen; Tripathi, Dhananjay (eds). Afghanistan Post-2014. Power configurations and evolving trajectories, Io6-127. New Delhi-London-New York: Routledge.

Baubek, Somzhurek; Yessengalieva, Anna; Elmira Adil. 2015. Shanghai Cooperation Organization and its Activities in Ensuring Human and Social Security, The Anthropologist, 22:3, 5IO-5I7, DOI: 10.1080/09720073.2015.11891909

Behnke, Andreas. 20I3. NATO's Security Discourse after the Cold War. Representing the West. London-New York: Routledge.

Bindi, Federiga. 20I5. "Transatlantic Foreign Policy Cooperation in the Obama Era”. In: Buonanno, Laurie; Cugleșan, Natalia; Henderson, Keith (eds). The New and Changing Transatlanticism. Politics and policy perspectives, 43-59. London-New York: Routledge.

Bishkek Declaration of Heads of states of the SCO. Available on: http://www. scosummit2013.org/en/documents/bishkekskaya-deklaratsiya/. access on: September, 202019.

Brussels Summit Declaration Issued by the Heads of State and Government participating in the meeting of the North Atlantic Council in Brussels 1112 July 2018. 2018. Brussels. I2 July. Available on: https://www.nato. int/cps/en/natohq/official_texts_I56624.htm. access on: March, 2I 2019 .

Bryanski, Gleb; Buckley, Chris. 20ı2. China's Hu Sees Role for Regional Bloc 
in Afghanistan, Chicago Tribune, 6 June. Available on: https://www. reuters.com/article/us-china-russia-hu-afghanistan/chinas-hu-seesrole-for-regional-bloc-in-afghanistan-idUSBRE85504T20120606. access on: September, 202019.

Byrd, William A. (20I4). Who Will Pay for Afghan Security Forces?. I2 June 20I4. Available on: http://foreignpolicy.com/20I4/06/ı2/who-willpay-for-afghan-security-forces/. access on: March, 252019.

Charter of the SCO. Available on: www.sectsco.org/en/documents. access on: September, 202019.

Convention on Terrorism, Extremism and Separatism of the SCO. Available on: www.sectsco.org/en/documents. access on: September, 202019.

Cortright, David. 20I6. Ending Obama's War. Responsible Military Withdrawal from Afghanistan. London-New York: Routledge.

Doorstep Statement by NATO Secretary General Jens Stoltenberg Ahead of the NATO Leaders' Meeting. 20I7. Brussels. 25 May. Available on: https:// nato.usmission.gov/may-25-20I7-stoltenberg-doorstep/. access on: March, 25 20I9.

Huasheng, Zhao. 20I2. China and Afghanistan. China's interests, stances, and perspectives, A report of the CSIS Russia and Eurasia program, March.

Joint Communiqué of the Meeting of Council of Heads of states of the SCO on June 15, 2011 in Astana. 20II. Available on: www.sco2orr.kz/en/kzsco/ astana.php. access on: September, 202019.

Joint Statement on the Resolute Support Mission in Afghanistan. 2018. Brussels. 12 July. Available on: https://www.nato.int/cps/en/natohq/official_ texts_I56625.htm. II.09.2018. access on: March, 21 2019.

Jureńczyk, Łukasz. 2oi6. "Afghanistan in the Chicago and Wales NATO Summit Declarations”. In: Ušiak, Jaroslav; Kollár, Dávid; Melková, Michaela (eds). Security Forum 2016. Volume of Scientific Papers, Banská Bystrica: Univerzity Mateja Bela v Banskej Bystrici.

Keane, Conor. 20I6. UN-Nation Building in Afghanistan. London-New York: Routledge.

Kerton-Johnson, Nicholas. 20II. Justifying America's Wars. London-New York: Routledge.

Renshon, Stanley A. 2010. National Security in the Obama Administration. Reassessing the Bush Doctrine. London-New York: Routledge.

Khan, Raja M. 20I5. China's Economic and Strategic Interests in Afghanistan. FWU Journal of Social Sciences, Special Issue, Winter, Vol.I, No.2: IO4III. 
Khan, Simbal. 2009. Stabilization of Afghanistan: US-NATO regional strategy and the role of the SCO. Institute of Strategic studies. Islamabad. Available on: http://www.issi.org.pk/wp-content/ uploads/2014/06/1299137179-72323919.pdf. access on: October, 7 2019 .

Kitchen, Veronica M. 20I0. The Globalization of NATO. Intervention, security and identity. London-New York: Routledge.

Lagadec, Erwan. 2012. Transatlantic Relations in the 21st Century. Europe, America and the rise of the rest. London-New York: Routledge.

Larsen, Jeffrey A. 20I7. "NATO's responses to Russian belligerence: an overview". In: Friis, Karsten (ed.). NATO and Collective Defence in the 21st Century. An Assessment of the Warsaw Summit, 8-I5. London-New York: Routledge.

Lawless, Garrett J.; Constantineau, Philippe; Dizboni, Ali. 20I7. A Hermeneutic Analysis of Military Operations in Afghanistan. New York: Palgrave Macmillan.

Lindley-French, Julian. 2013. "Pulling together? NATO operations in Afghanistan". In: Herd, Graeme P.; Kriendler, John (eds). Understanding NATO in the 21st Century. Alliance strategies, security and global governance, II9-I34. London-New York: Routledge.

London Declaration Issued by the Heads of State and Government participating in the meeting of the North Atlantic Council in London 3-4 December 2019. 2019. London. 4 December. Available on: https://www.nato.int/cps/ en/natohq/official_texts_I7I584.htm. access on: December, 72019.

McCrisken, Trevor. 20I4. "Obama's war on terrorism in rhetoric and practice". In: Bentley, Michelle; Holland, Jack (eds). Obama's foreign policy. Ending the War on Terror, I7-44. London-New York: Routledge.

Mulrooney, David. 2013. Security and Development in Afghanistan after 2014. Conference report 6th Annual ISDP-AMS Conference, December 6-8.

NATO-Afghanistan relations. 20I8. July. Available on: https://www.nato. int/nato_static_fl20I4/assets/pdf/pdf_2018_07/20180706_I807backgrounder-afghanistan-en.pdf. access on: March, 252019.

NATO and Afghanistan. 2018. 27 November. Available on: https://www.nato. int/cps/en/natohq/topics_8I89.htm. access on: March, 252019.

Nopens, Patrick. 20I4. The impact of the withdrawal from Afghanistan on Russia's Security, Security Policy Brief No.54, March. EGMONT Royal Institute for IR Brussels. 
Norberg, Johan. 2013. High Ambitions, Harsh Realities. Gradually Building the CSTO's Capacity for Military Intervention in Crises, FOI-R-3668-SE, May.

Orfy, Mohammed Moustafa. 2oII. NATO and the Middle East. The geopolitical contexts post-9/11. London-New-York: Routledge.

Qassem, Ahmad Shayeq. 2009. Afghanistan's Political Stability. A Dream Unrealised. London-New York: Routledge.

Quinn Adam. 20I4. "Realism and US foreign policy". In: Parmar, Inderjeet; Miller, Linda B.; Ledwidge, Mark (eds). Obama and the World. New directions in US foreign policy. Second edition, 3-I4. London-New York: Routledge.

Pease, Kelly-Kate. 2008. International Organizations. Perspective son Governance in Twenty first century, 3rd edition. New Jersey: Pearson Prentice Hall.

Reeves, Jeffrey. 20I4. The Shanghai Cooperation Organization: A tenable provider of security in Post-2014 Central Asia? Asia-Pacific Center for Security Studies. Available on: https://apcss.org/wp-content/ uploads/20I4/o6/SCO-REEVES-20I4.pdf. access on: October, 7 20I9.

Remarks by Yang Jiechi Minister for foreign affairs of China at the international Afghanistan conference. 20II. Bonn. December 5. Available on: http:// in.china-embassy.org/eng/xwfw/xxfb/t884629.htm. access on: September, 20 20I9.

Resolute Support Mission in Afghanistan. 2018. I8 July. Available on: https:// www.nato.int/cps/en/natohq/topics_iI3694.htm. access on: March, 252019 .

Ringsmose, Jens. 20I6. “NATO: a public goods provider”. In: Webber, Mark; Hyde-Price, Adrian (eds). Theorising NATO. New perspectives on the Atlantic alliance, 2OI-222. London-New York: Routledge.

Ruttig, Thomas. 20I4. "Afghanistan between democratization and civil war: post- 20I4 scenarios", In: Krause, Joachim; Mallory, Charles King IV. (eds). Afghanistan, Pakistan and Strategic Change. Adjusting Western regional policy, I7I-200. London-New York: Routledge.

Schimmelfennig, Frank. 20I6. "NATO and institutional theories of international relations". In: Webber, Mark; Hyde-Price, Adrian (eds). Theorising NATO. New perspectives on the Atlantic alliance, 93-II5. London-New York: Routledge.

Schweller, Randall L.; Priess, David. I997. A Tale of Two Realisms: Expanding 
the Institutions Debate, Mershon International Studies Review, Vol. 4I, No. I (May), pp. I-32

Simoni, Serena. 20I3. Understanding Transatlantic Relations. Whither the West?. London-New York: Routledge.

Stepanova, Ekaterina. 2013. Afghanistan after 2014: The way forward for Russia, IFRI, Russie. Nei.Visions No7i, May.

Stepanova, Ekaterina. 20I3. Russia's concern relating to Afghanistan and the broader region in the context of the US/NATO withdrawal. CIDOB Policy Research Project, June.

Terzuolo, Eric. 2006. NATO and Weapons of Mass Destruction. Regional alliance, global threats. London-New York: Routledge.

Trenin, Dmitri; Kulakov, Oleg; Malashenko, Alexey; Topychkanov, Petr. 2014. A Russian Strategy for Afghanistan after the coalition troop withdrawal, Carnegie Moscow Center, May.

Treverton, Gregory F. 20I6. "A Post-Modern Transatlantic Alliance”. In: Ilgen, Thomas L. (ed.). Hard Power, Soft Power and the Future of Transatlantic Relations, 39-58. London-New York: Routledge.

Vielmini, Fabrizio. 2012. The SCO-Central Asian dimension of the Afghan crisis on the eve of ISAF retreat, Institute for studying international politics No I32, July.

Wales Summit Declaration Issued by the Heads of State and Government participating in the meeting of the North Atlantic Council in Wales. 2014. Newport. 5 September. Available on: https://www.nato.int/cps/ic/ natohq/official_texts_II2964.htm. access on: March, 2I 2019.

Wales Summit Declaration on Afghanistan Issued by the Heads of State and Government of Allies and their International Security Assistance Force (ISAF) troop contributing partners. 20I4. Newport. 4 September. Available on: https://www.nato.int/cps/ic/natohq/news_II25I7.htm. access on: March, 21 2019.

Warsaw Summit Communiqué Issued by the Heads of State and Government participating in the meeting of the North Atlantic Council in Warsaw 8-9 July 2016. 20I6. Warsaw. 9 July. Available on: https://www.nato.int/ cps/ic/natohq/official_texts_I33169.htm. access on: March, 21 2019.

Warsaw Summit Declaration on Afghanistan Issued by the Heads of State and Government of Afghanistan and Allies and their Resolute Support Operational Partners. 20I6. Warsaw. 9 July. Available on: https://www. nato.int/cps/en/natohq/official_texts_I33I7I.htm. access on: March, 2I 2019. 


\section{ABSTRACT}

The main research question of the article is what attitude present the North Atlantic Treaty Organization, the Shanghai Cooperation Organisation and the Collective Security Treaty Organization towards Afghanistan after 20I4? A number of detailed questions were also put to help to answer the main question. The article consists of eight sections. The first discusses the methodological assumptions of the article. Section two covers literature review and theoretical framework of the article. The following sections include an analysis of the approach to Afghanistan of the three indicated international organizations. The article ends with conclusion that contain the main theses.

\section{KEYWORDS}

Afghanistan; NATO; SCO; CSTO.

Received on December 29, 2019 Approved on May 8, 2020 